\title{
Effect of vitamin $C$ treatment on some central nervous system functions in young rats whose mothers treated with hydrogen peroxide during the lactation period
}

\author{
A.Y. Jasim ${ }^{1}\left(\right.$ and S.A. Rasheed ${ }^{2} \odot$ \\ ${ }^{1}$ Department of Animal Production, Technical Institute Mosul, Northern Technical University, ${ }^{2}$ Department of physiology, \\ Biochemistry and Pharmacology, College of Veterinary Medicine, University of Mosul, Mosul, Iraq
}

\section{Article information}

Article history:

Received August 6, 2020

Accepted January 23, 2021

Available online October 1, 2021

\section{Keywords:}

Hydrogen peroxide

Nervous system

Oxidative stress

Rats

Vitamin C

\section{Correspondence}

S.A. Rasheed

suharasheed@yahoo.com

\begin{abstract}
This study was designed to evaluate the effect of vitamin on young rats whose mothers exposed to $1 \%$ hydrogen peroxide in drinking water during the lactation period on the function of the nervous system. The study consisted of three groups, Control group, hydrogen peroxide group, vitamin $\mathrm{C}$ with hydrogen peroxide group, showed that treatment with hydrogen peroxide for mothers led to significant decrease in the weights of youngrats-age21 days and significant increase in the righting reflex test, cliff avoidance and the olfactory discrimination test in young rats at age of week and also in the onset movement test and at the time of negative geotaxis test in-young-rats age21days. Treatment of mothers with hydrogen peroxide caused significant decrease in open-field activity and number of times standing on backlists during 3minutes and in the approach response, touch and sound of young rats at age 21 days. While, hydrogen peroxide treated group resulted in significant increase in time of negative geotaxis test and hydrogen peroxide had no effect on response of tail pinch as compared to other groups. When treating mothers with vitamin $C$ significant increase in weights of youngsters age 21 days, as well as in onset of movement test and in number of squares cutoff within 3minutes in open-field activity and number of times standing on backlists during 3minutes in young-rats age 21 days. Also there was significant decrease in righting reflex test, olfactory distinction and negative geotaxis test compared to hydrogen peroxide treated group. It was concluded from the study that vitamin $\mathrm{C}$ plays an important role as an antioxidant by improving the nervous system function in young rats their mothers exposed to with hydrogen peroxide in drinking water.
\end{abstract}

DOI: 10.33899/ijvs.2021.127894.1544, (CAuthors, 2021, College of Veterinary Medicine, University of Mosul.

This is an open access article under the CC BY 4.0 license (http://creativecommons.org/licenses/by/4.0/).

\section{Introduction}

Oxygen is one of the necessary elements for life, and most of it is naturally reduced to water through breathing processes in mitochondria. As for the remainder of oxygen $1-2 \%$, it is exposed to incomplete reductive reactions through which radicals of the Superoxide anion radical, which is one of the most varieties of free radicals are toxic, other types of free oxygen roots that include hydrogen peroxide, hydroxyl radical, and singlet oxygen (1-3). Many studies confirm the role of oxidative stress in causing many pathological conditions by generating free radicals and effective oxygen classes (4), and free radicals are defined as molecules that have one or more than ten electrons in an unconfigured way in the outer envelope (5), and for these free radicals Toxic effects on the phospholipids present in the cell membrane, as they act to oxidize and form malondialdehyde (MDA) in a process called lipid 
peroxidation, and this leads to an increase in the membranous exudation of the membrane with impaired cell function (6). Several studies also confirmed that free radicals lead to a nervous system affliction with many diseases (7) and that young animals are most vulnerable to these toxic effects as the main source of exposure to these toxic substances is milk and that the lactating period is very important in the life of young people because it is characterized by rapid growth and development of nervous system, as the motor mechanics of these toxic substances in young people differ from adults, which makes the young at great risk (8), and that the period of brain tissue formation occurs at the last stage of pregnancy and lasts for 18 months after birth in humans and is called sudden growth Brain growing spurt, and in rats, the period of sudden brain development begins immediately after birth and reaches its climax on the tenth day of life, and this period is characterized by the formation of network communication and the creation of the two medulla (9). Vitamin C is one of the water soluble vitamins, this vitamin is stable in acidic solutions but it is very sensitive to oxidation, which is accelerated by the presence of copper salts and at high temperatures and exposure to air and light (10). Vitamin C is involved in accelerating the absorption of iron in the gut and contributes to making use of the iron stored in the body (11). Vitamin $\mathrm{C}$ is considered one of the most powerful natural antioxidants (12), as it is found in a large concentration in many tissues, and works as a sweeper for effective oxygen classes, especially radicals of negative superoxide, hydrogen peroxide, hydroxyl radical and singlet oxygen (13), Vitamin $\mathrm{C}$ is considered an important factor in preventing the effects of oxidative stress in poultry despite the manufacture of this vitamin in their bodies (14), and also vitamin $\mathrm{C}$ is an important factor in eliminating the neurological signs resulting from poisoning with sodium nitrate and causing the production of free radicals (15).

Many recent studies have confirmed the strength of this vitamin in reducing the severity of stress The oxidative process that results in the generation of the reactive oxygen species responsible for destroying the cells components (16-18). For this reason, this study aimed to use vitamin C and evaluate its effect on the efficiency of the nervous system in young rats his mothers exposed to hydrogen peroxide during the lactation period in drinking water.

\section{Materials and methods}

Female albino rats were used in this study at the age 100-120 day that weight ranged between $200-220 \mathrm{~g}$. The rats were reared under special laboratory conditions represented by a natural light cycle (10 hours of light and 14 hours of darkness) in special plastic cages prepared for this purpose and at a temperature of $18 \pm 2^{\circ} \mathrm{C}$, water and food were submitted adlibitum. Females were placed with adult males for fertilization at a ratio of 3: 1 , and then the mothers were isolated at the first day after birth with their offsprings, each in their cage, and the treatments were performed. The experiment included 3 groups. Mothers of the first group (G1) were given water and a regular diet during the 21 days of lactation. The second group (G2), the mothers were given $1 \%$ hydrogen peroxide (Al-Hayat Laboratory, Iraq) with drinking water, and the third group (G3) mothers were given vitamin C $500 \mathrm{mg} / \mathrm{kg}$ body weight (BDH, England) (19) using the intragastric gavage needle and the hydrogen peroxide $1 \%$ With drinking water, tests were conducted on the nervous system of young rats at the age of 21 days, including righting reflex test, cliff avoidance test and olfactory discrimination test as neurological behavioral tests, and onset of movement test, open- field activity negative geotaxis test as indicator for central nervous system activity. As well as, approach response, ouch response, click response and tail pinch response were measurement. Furthermore, weights of young rats, at one day and after 21 days old was recorded $(20,21)$.

The data were statistically analyzed using the Tukey's test and the difference was considered significant at the probability level $\mathrm{P}<0.05$ (22). Data for sensory and motor stimulatory responses in young rats at the age of 21 days were analyzed using Mann-Whitney-U- test for data that was in the form of numerical scores.

\section{Results}

The results showed in table 1 a significant decrease in the body weight of young rats their mothers treated with hydrogen peroxide for 21 days compared with the control group. While giving vitamin $\mathrm{C}$ to mothers for 21 days led to a significant increase in the weights of young rats compared to the weights of young rats their mothers treated with hydrogen peroxide.

Table 2 revealed a significant increase in Righting reflex test, Cliff avoidance and olfactory discrimination in young rats their mothers treated with hydrogen peroxide during a week of lactation compared with the control group. When giving vitamin $\mathrm{C}$ and hydrogen peroxide to mothers, a significant decrease was observed in a Righting reflex test and olfactory discrimination in young rats compared to the young rats their mothers treated with hydrogen peroxide for a week and values return to normal values of the control group, and no significant difference was recorded in the Cliff avoidance in young rats their mothers Treatment with hydrogen peroxide and vitamin $\mathrm{C}$ compared with young rats their mothers exposed to hydrogen peroxide at the age of a week, with a significant increase in the Cliff avoidance in young rats their mothers treated with hydrogen peroxide and vitamin $\mathrm{C}$ compared to control group in the first week of age.

The results of table 3 showed that the treatment of mothers with hydrogen peroxide led to a significant 
increase in the onset of movement test and negative geotaxis test in young rats at the age of 21 days compared to the young rats in control group, while a significant decrease was observed in the number of square moving during 3 minutes and the number The times of standing on the hind legs during 3 minutes for young rats at the age of 21 days and the rate their mothers treatment with hydrogen peroxide during the lactation period compared with the control group. When treating mothers with hydrogen peroxide and vitamin $\mathrm{C}$, a significant increase was observed in the number of square blocks during 3 minutes and the number of times standing on the hind legs during 3 minutes in young rats at the age of 21 days and returning to the control group. Also, a significant decrease was observed in the negative geotaxis test in the young rats, whose mothers treated with hydrogen peroxide and vitamin $\mathrm{C}$ at the age of 21 days when compared with the young rats group their mothers treated with hydrogen peroxide at the age of 21 days, and then return to the control group. Treatment with hydrogen peroxide and vitamin $\mathrm{C}$ did not cause a significant change in the young rats when compared with the young rats treated with hydrogen peroxide at the age of 21 days in the Onset of movement test, and a significant increase was observed in the Onset of movement test in the young rats group treated with hydrogen peroxide and vitamin $\mathrm{C}$ when compared with the control.

Table 4 showed that giving hydrogen peroxide to mothers resulted in a significant decrease in the Approach response, Touch response and click response in young rats at the age of 21 days compared with the control group, and no significant difference was observed in the Tail pinch response compared with control group. And the administration of vitamin $\mathrm{C}$ with hydrogen peroxide for mothers led to the return of Approach response, touch, click and tail pinch to the normal values of control.

Table 1: Effect of vitamin $\mathrm{C}$ on body weight of young rats

\begin{tabular}{lcc}
\hline Groups & \multicolumn{2}{c}{ means \pm SE $/ \mathrm{n}=10$ animals } \\
\cline { 2 - 3 } & One day old $(\mathrm{gm})$ & 21 day old $(\mathrm{gm})$ \\
\hline G1 & $4.4 \pm 0.05 \mathrm{a}$ & $27.55 \pm 0.71 \mathrm{~b}$ \\
G2 & $4.85 \pm 0.07 \mathrm{a}$ & $16.85 \pm 0.3 \mathrm{a}$ \\
G3 & $4.8 \pm 0.05 \mathrm{a}$ & $28.25 \pm 0.52 \mathrm{~b}$ \\
\hline
\end{tabular}

Different letters in each column refer to significance $\mathrm{P} \leq 0.05$.

Table 2: The effect of vitamin $\mathrm{C}$ on neurological behavior measurements in young rats at the age of one week

\begin{tabular}{lccc}
\hline & \multicolumn{3}{c}{ means \pm SE $/ \mathrm{n}=10$ animals } \\
\cline { 2 - 4 } Groups & Righting & Cliff & Olfactory \\
& Reflex & Avoidance & Discrimination \\
\hline G1 & $2.7 \pm 0.2 \mathrm{a}$ & $10.6 \pm 0.3 \mathrm{a}$ & $15.4 \pm 0.8 \mathrm{a}$ \\
G2 & $6.95 \pm 0.7 \mathrm{~b}$ & $12.85 \pm 0.7 \mathrm{~b}$ & $30 \pm 1.3 \mathrm{~b}$ \\
G3 & $2.9 \pm 0.4 \mathrm{a}$ & $13.05 \pm 0.9 \mathrm{~b}$ & $16.9 \pm 2.1 \mathrm{a}$ \\
\hline
\end{tabular}

Different letters in each column refer to significance $\mathrm{P} \leq 0.05$.

Table 3: The effect of vitamin $\mathrm{C}$ on neurological behavior measurements in young rats at the age of 21days

\begin{tabular}{lcccc}
\hline Groups & \multicolumn{4}{c}{ means \pm SE $/ \mathrm{n}=10$ animals } \\
\cline { 2 - 5 } & Onset of Movement & Open-Field activity & No. of standing on the back legs & Negative Geotaxis \\
\hline G1 & $2.55 \pm 0.42 \mathrm{a}$ & $56.3 \pm 2.4 \mathrm{~b}$ & $7.9 \pm 0.5 \mathrm{~b}$ & $4.4 \pm 0.2 \mathrm{a}$ \\
G2 & $5.9 \pm 0.31 \mathrm{~b}$ & $20.7 \pm 1.5 \mathrm{a}$ & $4.05 \pm 0.42 \mathrm{a}$ & $12.65 \pm 0.9 \mathrm{~b}$ \\
$\mathrm{G} 3$ & $5.1 \pm 0.4 \mathrm{~b}$ & $55.5 \pm 2.1 \mathrm{~b}$ & $7.4 \pm 0.3 \mathrm{~b}$ & $5.05 \pm 0.4 \mathrm{a}$ \\
\hline
\end{tabular}

Different letters in each column refer to significance $\mathrm{P} \leq 0.05$.

Table 4: The effect of vitamin $C$ treatment on sensory and motor stimulatory response in young rats at the age of 21days

\begin{tabular}{lcccc}
\hline \multirow{2}{*}{ Groups } & \multicolumn{4}{c}{ means $\pm \mathrm{SE} / \mathrm{n}=10$ animals } \\
\cline { 2 - 5 } & Approach Response & Touch Response & Click Response & Tail Pinch Response \\
\hline G1 & $3 \pm 0.0$ & $2 \pm 0.2$ & $4 \pm 0.0$ & $3 \pm 0.0$ \\
G2 & $1.5 \pm 0.0^{*}$ & $0.8 \pm 0.0^{*}$ & $2.8 \pm 0.3^{*}$ & $2.9 \pm 0.5$ \\
G3 & $3 \pm 0.0$ & $2.3 \pm 0.0$ & $3.8 \pm 0.3$ & $3.1 \pm 0.0$ \\
\hline
\end{tabular}

* Means a significant difference compared with control group.

\section{Discussion}

This study is concerned with observing the effect of antioxidants represented by vitamin $\mathrm{C}$ on some nervous system functions of young rats whose mothers are exposed to oxidative stress-induced with hydrogen peroxide with drinking water. The results of the study showed a significant decrease in the weights of young rats his mothers treated with hydrogen peroxide at the age of 21 days, which is due to the decrease in the amount of feed consumed by the young, and this is consistent with the findings of Aziz (23), which is due to the increase in the active oxygen varieties that deplete glutathione and catalase as antioxidants (24). Meanwhile, the results revealed that 
giving vitamin $\mathrm{C}$ for 21 days led to a significant increase in the body weights of the young rats and this is in line with what Al-Taie reached (19) as vitamin C is the first line of defense against oxidative stress and thus works to improve the animal's ability for food intakes (25). The study also showed a significant increase in reflex tests to correct the posture of the body and avoid high edge and olfactory discrimination in young rats at the age of a week when treating their mothers with hydrogen peroxide during lactation and this is due to changes in the metabolism of neurotransmitters in the central nervous system and the occurrence of neuropathy in the brain, spinal cord and peripheral nerves (26), Where the neurotransmitters play an important role in the function of the central nervous system and they interact with each other in a complex way, acetylcholine plays an important role in learning and memory (27). The administration of hydrogen peroxide also resulted in a significant increase in the onset of movement test and the negative geotaxis test, a decrease in the number of square blocks and the number of times standing on the back legs within 3 minutes, the reason for this is that hydrogen peroxide generates free radicals that lead to neuropathy in the brain and spinal cord an surrounding nerves, which affect the neurotransmitters, the chemical and serotoninergic system, which lead to the breaking down of the cell membrane, the release of proteins and the destruction of the DNA of the neurons in young rats his mothers treated with hydrogen peroxide (27), This is in agreement with the findings of Mustafa and Al-Baggou (28) that administration of chlorpyrifos and deltamethrin in mice led to a significant decrease in the open field and a significant increase in the time of completion of negative geotaxis test, Qasim (15) also found that the administration of sodium nitrate led to a significant decrease in motor activity within the open field, and this is consistent with the findings of the current study, while the current study did not agree with Qasim's findings in the negative geotaxis test (15), this is consistent with the findings of Qasim (15), where the study proved that vitamin $\mathrm{C}$ has antioxidant effects on the functions of the nervous system, Hassan (12) also, found that vitamin $\mathrm{C}$ reduced the effects of heat stress in broilers.

The current study showed a significant decrease in the catalytic response to the approach, touch and click in young rats at the age of 21 days when their mothers treated with hydrogen peroxide and perhaps the reason for that is due to neuropathy, which is one of the diseases of the nervous system due to the generation of reactive oxygen species that have a major role in sabotaging the brain cells, spinal cord and nerves Surrounding it which leads to a change in the metabolism of the neurotransmitters in the nervous system (29).

Giving vitamin $\mathrm{C}$ with hydrogen peroxide for mothers has significantly increased the stimulatory response to approaching, touching, sound or crackling in young rats at the age of 21 days. This is due to the role of vitamin $\mathrm{C}$ in protecting against oxidation, as well as having an important role in the synthesis of peptides in the peptide amidation and myelin formation and protection neural synapses from free radicals as well as protecting neurons from glutamate toxicity caused by free radicals (29).

\section{Conclusions}

It was concluded from this study that the use of vitamin $\mathrm{C}$ has an important role in ameliorating the dysfunction of nervous system in young rats their mothers treated with hydrogen peroxide during the lactation period.

\section{Acknowledgment}

This study was supported by the College of Veterinary Medicine, Mosul University. The authors thanks laboratory animal house for providing animals.

\section{Conflict of interest}

There is no conflict of interest.

\section{References}

1. Bulk ley GB. The role of oxygen free radicals in human disease processes. Surg. 1983;94(3):407-411. Doi: 10.5555/uri:pii:0039606083900326

2. McCord JM. The superoxide free radical: Biochemistry and $\begin{array}{llll}\text { pathophysiology. } & \text { Surg. } & 1983 ; 94(3): 412-414 . & \text { Doi: }\end{array}$ 10.5555/uri:pii:0039606083900338.

3. McCord JM. Defense against free radicals has therapeutic implications. JAMA 1984;251:2187-2192. Doi: DOI: $10.1001 /$ jama.251.17.2187

4. Halliwell B, Gutteridge JMC. Oxygen radicals and the nervous system. Trends NeuroSc 1985;8:22-6. Doi: 10.1016/01662236(85)90010-4

5. Hsu PC, Liu MY, Hsu CC, Chen LY, Guo YL. Effect of vitamin E and /or Con reactive oxygen species - related lead toxicity in rat sperm. Toxicology 1998;J 128:169-179. Doi: 10.1016/S0300483X(98)00068-7

6. Halliwell B, Gutteridge JMC. Lipid peroxidation, oxygen radicals, cell damage and antioxidant therapy. Lancet 1984;1:1396-1397. Doi: $\underline{10.1016 / \mathrm{s} 0140-6736(84) 91886-5}$

7. Ahibon E, Grandison L, Banfoco E, Zhivotovsky B, Ceccatelli S. Androgen treatment of neonatal rats decreases susceptibility of cerebellar granule neurons to oxidative stress in vitro. Eur J Neurosci. 1999;11:1285-1291. Doi: 10.1046/j.1460-9568.1999.00529.x

8. Rice D, Barone S. Critical period of vulnerability for the developing nervous system evidence from human and animal model. Environ Heal Res. 2000;108(3):511-533. Doi: 10.1289/ehp.00108s3511

9. Innis S. Essential fatty acids in growth and development. Prog Lipid Res. 1991;30(1):39-103. Doi: 10.1016/0163-7827(91)90006-q

10. Halliwell B. Free radicals, antioxidants and human disease: Curiosity, cause or consequence. Lancet. 1994;344:721-724. Doi: 10.1016/s0140-6736(94)92211-x

11. Barker BM, Bender DA. Vitamins in medicine. $4^{\text {th }}$ Edition, London: William Heinemann Medical Book; 1980. https://www.worldcat.org/title/vitamins-inmedicine/oclc/869551613?referer=di\&ht=edition . 
12. Hassan AA, Asim RA. Effect of vitamin C and acetylsalicylic acid supplementation on some hematological value, heat shock protein 70 concentration and growth hormone level in broiler exposed to heat $\begin{array}{llllll}\text { stress. Iraqi J Vet Sci. 2020;34 (2):357-363. Doi: } & \end{array}$ 10.33899/ijvs.2019.125950.1195

13. Ball BA, Medina V, Gravancem CG, Baumber J. Effect of antioxidants on preservation of motility, viability and acrosomal integrity of equine spermatozoa during storage at $5^{\circ} \mathrm{C}$. Theriogenol. 2001;56:577-589. Doi:10.1016/s0093-691x(01)00590-8 .

14. Adenkola AY, Angani MT. Ascorbic acid supplementation effect on hematology and oxidative stress parameters of broiler chicken during the hot-dry season in southern Guinea Savannah. J Poult Res. 2017;14(1):28-33. [available here

15. Qasim HO. The antagonism effect of sodium nitrate by ascorbic acid (vitamin $\mathrm{C}$ ) on neurobehavioral of mice. Iraqi $\mathbf{J}$ Vet Sci. 2020;34(2):241-245. Doi: 10.33899/ijvs.2019.125863.1169

16. Goldfarb AH. Antioxidants: Role of supplementation to prevent exercise- induced oxidative stress. J Am Coll Sport Med 1993; 25(2):232-6. [available here]

17. Zhang J, Jiang S, Watson RR. Antioxidant supplemention prevents oxidation and inflammatory responses induced by sidestream cigarette smoke in old mice. Environ Heal Persp. 2001;109:1007-1009. Doi: 10.1289/ehp.011091007

18. Kitti S, Andras P, Edina H, Zsuzsanna M, Agnes F, Edit H, Judit K, Edit P, Andrea S. Green Tea and Vitamin C ameliorate some neurofunctional and biochemical signs of arsenic toxicity in rats. Nutr Neurosci. 2016;19(3):102-9. Doi: 10.1179/1476830514Y.0000000151

19. Al-Taei AYJ. Effect of vitamin $\mathrm{C}$ on some testicular functions in rats exposed to oxidative stress induced by hydrogen peroxide [Master's thesis]. Mosul: College of Veterinary Medicine, University of Mosul; 2003.

20. Al-Badrany YMA, Mohammad FK. Effects of acute andrepeated oral exposure to the organophosphate insecticide chlorpyrifos on openfield activity in chicks. Toxicol Let. 2007;174:110-116. Doi: 10.1016/j.toxlet.2007.09.001

21. Hassan AA, Abdul Alrasool EM, Jasem HM. Effect of cadmium on CNS function and development in rat offspring: Effect of vitamin $E$. Iraqi J Vet Sci. 2008;22(1):31-37. Doi: 10.33899/ijvs.2008.5658

22. Bruning JL, Kintz BL. Computation handbook of statistics. Illinois: Foresmam Co; 1977

23. Aziz BN. Effect of hydrogen peroxide - induced oxidative stress on epididymal sperms of mice. Iraqi J Vet Sci 2000;13(1):61-65. [available here]

24. Jahangir T, Khan TH, Prasad L, Sultana S. Pluchea lanceolata attenuates cadmium chloride induced oxidative stress and genotoxicity in swiss albino mice. J Pharm Pharmacol. 2005;57(9):1199-1204. Doi: 10.1211/jpp.57.9.0015

25. Frei B. On the role of vitamin $C$ and other antioxidants in atherogenesis and vascular dysfunction. PSEBM. 1999;222:196-204. Doi: $10.1046 / j .1525-1373.1999 . d 01-136 . x$

26. Singh RP, Sharad S, Kapur S. Free radicals and oxidative stress in neurodegenerative disease. JIACM. 2004;5(3):218-25. [available here]

27. Decker MW, McGaugh JL. The role of interaction between the cholinergic system and other neuromodulatory system in learning and memory. Synapse. 1991;7(2):151-68. Doi: 10.1002/syn.890070209

28. Mustafa KA, Al-Baggou BKh. Toxicological and neurobehavioral effects of chlorpyrifos and deltamethrin insecticides in mice. Iraqi $\mathbf{J}$ Vet Sci. 2020;34(1):189-196. Doi: 10.33899/ijvs.2019.125738.1144

29. Yu H, Liu S, Li M, Wu B. Influence of diet, vitamin, tea, trace elements and exogenous antioxidants on arsenic metabolism and toxicity. Environ Geochem Heal. 2016;38(2):339-51. Doi: $\underline{10.1007 / s 10653-015-9742-8}$

\section{تأثير المعاملة بفيتامين هـ في بعض وظائف الجهاز

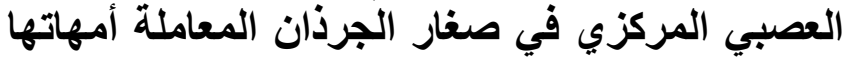 ببيروكسيد الهيدروجين أثناء فترة الرضاعة الجرذان}

أفراح يونس جاسم' و سهى عبد الكريم رشيد

'قسم الإنتاج الحيواني، المعهد التقني في الموصل، الجامعة التقنية

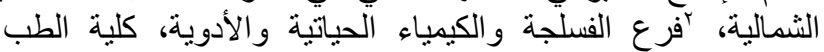

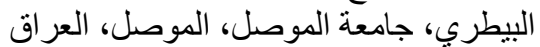

الخلاصة

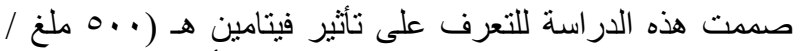

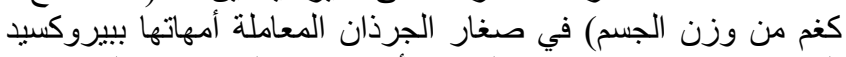

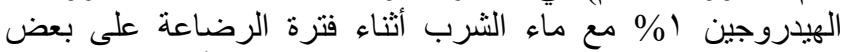

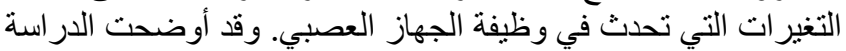
التي شملت ثناث مجاميع، مجموعة السيطرة ومجموعة وفئ بيروكسيد

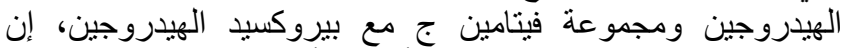

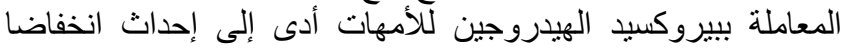

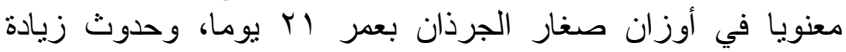
معنوية في اختبار منعكس تصحيح وضع الجسم وتجنب الحافة و اختبار

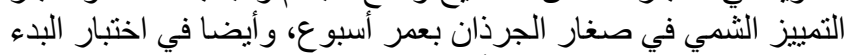

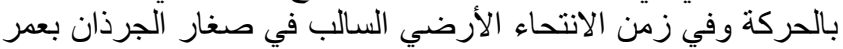

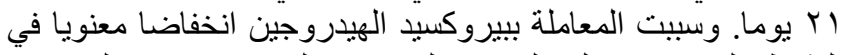

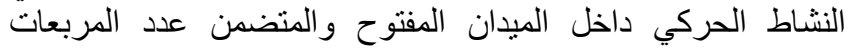

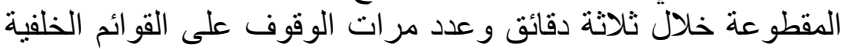

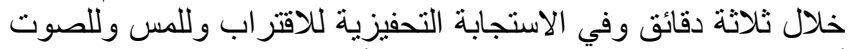

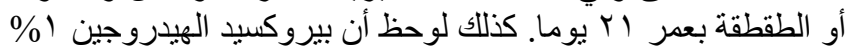

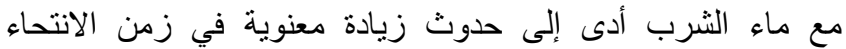

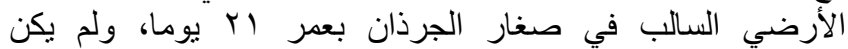
لبيروكسيد الهيدروجين تأثير على الاستجابة التحفيزية لقرص صارئ الذيل في

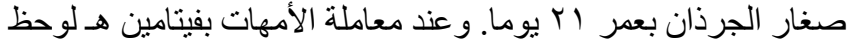

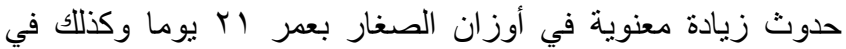

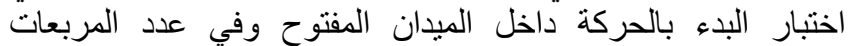

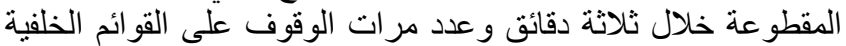

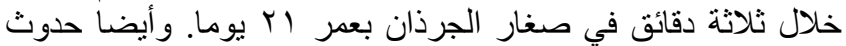
انخفاضا معنويا في اختبار منعكس تصحيح وضي وضع الجسم والتمييز

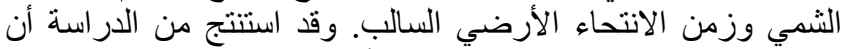

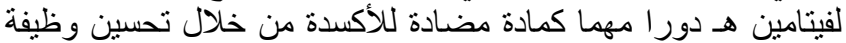
الجهاز العصبي في صغار الجرذان المعاملة أمهاتها ببيروكسيد

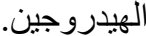

